Nikola Ćurčić ${ }^{1}$

Institute of Agricultural Economics, Belgrade

Ivan Piljan ${ }^{2}$

College of Business Economics and Entrepreneurship, Belgrade

\section{Zoran Simonović ${ }^{3}$}

Institute of Agricultural Economics, Belgrade
ORIGINAL SCIENTIFIC ARTICLE doi:10.5937/ekonomika1903021C

Received: August 02. 2019. Accepted: September, 09. 2019.

\title{
MARKETING CONCEPT IN INSURANCE COMPANIES ${ }^{4}$
}

\begin{abstract}
The aim of the research in this paper is the process of selling insurance services, as the most important business area of every insurance company. This process is viewed from the marketing and distribution angle in classic insurance sales through traditional sales channels.

The insured must be at the center of all future insurance activities of the insurance company. Satisfying the needs of the insured is a basic precondition for the successful sale of insurance services, so for every insurance company it is necessary to implement this in its strategy through business policy and business culture.

The insurance service can be distributed by different sales channels. It is important that these sales channels ensure the availability of the insurance service at the right time, in the right place and in the appropriate quantities.

The paper deals with classical marketing and traditional distribution channels in the function of insurance sales.
\end{abstract}

Key words: insurance, sale of insurance services, classical marketing, traditional distribution channels.

JEL classification: $G 22, G 23, M 31$

\section{МАРКЕТИНГ КОНЦЕПТ У ДРУШТВИМА ЗА ОСИГУРАҢЕ}

\section{Апстракт}

Циљ истраживања у овом раду је процес продаје услуга осигурања, као најважнија област пословања сваког друштва за осигурање. Овај прочес је сагледан из угла маркетинга и дистрибуцчје у класичној продаји осигурања кроз традиџионалне канале продаје.

\footnotetext{
${ }^{1}$ nikolavcurcic@yahoo.com

2 ivan.piljan@vspep.edu.rs

${ }^{3}$ zoki@medianis.net

${ }^{4}$ Article is part of project III - 46006 ,Sustainable agriculture and rural development in the function of accomplishing strategic objectives of the Republic of Serbia in the Danube region“, financed by the Ministry of Education, Science and Technological Development of the Republic of Serbia in the period 2011-2019.
} 
Осигураник мора бити у средишту свих будућих активности друштава за осигурање. Задовољење потреба осигураника је основни предуслов за успешну продају услуга осигурања, па је за свако друштво за осигурање неопходно да ово имплементира у своју стратегију кроз пословну политику и пословну културу.

Услуга осигурања може се дистрибуирати различитим продајним каналима. Битно је да ти продајни канали осигуравају расположивост услуге осигурања у право време, на правом месту и у одговарајућим количинама.

Кључне речи: осигурање, продаја услуга осигурања, класични маркетинг, традиционални канали дистрибуције.

\section{Introduction}

In the underdeveloped financial market, such as the Serbian one, in the previous period there was noticeable absence of serious competition and limited choice of financial services on the market. In such an environment, the development of a new financial market, first banking and securities markets, and then insurance, which, after tightening the criteria for business for insurance companies, has entered a new phase of development since 2004, the main feature of which was the strengthening competitiveness and the struggle to attract clients.

From that moment on, insurance marketing gets the significance it did not have before, and even though not all insurance companies operating on the Serbian market had the same importance, it is obvious that the relationship of almost all companies towards this important function of insurance is obvious. With the intensification of competitive relations between societies, it is logical to conclude that the importance of insurance marketing will grow in time.

Marketing is a discipline that deals with market issues, market needs and how to meet those needs. Marketing, as a business philosophy of intensive production, places at the center of its interest the analysis and consideration of all problems related to the turnover and sale of goods from producers to consumers. (Simonović et al, 2012, p. 102-109)

It can be freely stated that sales are one of the basic and at the same time the most important marketing functions in every insurance company. The implementation of this function is in the greatest direct correlation with the overall success of the entire insurance company. In order for a company to be able to successfully sell insurance services, the sales function must be treated as part of integral marketing. This means that it is necessary to plan and generate such insurance services that will, by their quality, price, availability and competitive advantage, meet the needs of potential customers of insurance services, or future insurers

The insurance company must be well aware of its target insurance market, perform the necessary research (such as market segmentation) on a regular basis, then analyze all chances and threats in its environment related to policy, legal solutions, competition activities and the like, then good examine their own strengths and weaknesses in terms of organization, personnel competence, capital adequacy, their own image in public and the like, and on that 
basis direct sales potentials to those market segments and sales channels that will be the most optimal for the company and give the best results. (Piljan et al, 2017, p.78)

\section{Satisfaction of the insured in the function of sale}

The condition and indicator of successful business of a modern organization is ensuring the satisfaction of all users who influence the achievement of its goals. The fact is that most Serbian insurance companies today are not sufficiently competitive in the global market. (Militeić et al, 2019, p. 289-304)

- In order for the insured to be satisfied with the insurance service, and the insurance company has successfully achieved the sales function, it is necessary to take into account the following factors:

- The quality of the insurance service, which implies the relationship of the company towards the insured before the conclusion of the insurance contract, for the duration and after the expiration of the contract. The insurance premium quality, including the consideration of market needs and opportunities, and the activities of competing insurance companies,

- Adequate selection of sales channels so that the insurance company always gets the most optimal sales effects for each insurance service individually,

- Promotional mix, and motivation of staff, who should dispose of appropriate knowledge and skills.

- The speed and the correct attitude of the insurance company towards the insured in case of compensation for damage or payment of the insured sum is the most important factor in creating the trust, safety and satisfaction of the insured, which in the end leads to the creation of loyalty of the insured towards the company and better sales results, and ultimately to the formation of a stable risk portfolio as the ultimate goal of every insurance company, which ultimately leads to the creation of a profit for society.

\section{Insurance market}

The market can be defined differently. One of the definitions could be that the market is the place where the sale of products and services takes place. The market can also be considered a relationship of supply and demand for a particular product or service.

For the insurance services market, it would be the most appropriate definition that it represents the ratio of the demand of individuals and companies that have the need to contract - by purchasing certain insurance services, or they are legally required, and with this need have adequate payment capacity, the desire to meet this need, and authorization for contracting or purchasing insurance services. All four of these factors are important for defining the demand market (need, payment capacity, desire and authority), and the absence of any of these factors negates the existence of the insurance market in the full sense. (Njegomir, 2011, p. 73-84)

In order for the insurance market to function on it, both contracting parties must actively participate: both insurance service providers and providers of such services insurance companies. 
The potential market for insurance services is the sum of all existing insurers and those who for the first time conclude or intend to renew the insurance contract with existing insurance companies, as well as those groups of individuals and legal entities that have all the preconditions for becoming insured.

In order to obtain data on the potentials of the insurance market it is necessary to answer the following key issues:

- Who does the market?

- What is being bought on the market, or what insurance services?

- Why do insurers purchase certain insurance services?

- Which categories of clients most often buy certain insurance services?

- How is insurance purchased, or through which sales channels is taking place?

- When do insurers buy insurance, or at what time intervals?

- Where are they most often buying, or in what places?

We consider the target market for insurance services as individuals and groups to whom the insurance company can offer insurance services in a particular area. When registering and selecting the insurance services to be dealt with, insurance companies define their potential market, or their target market. If the insurance company is registered for life insurance, then the target market of such a company is different from the target market of the company registered for non-life insurance.

A company registered for carrying out reinsurance activities knows that the target market for its services is related to insurance companies, which transfer part of the risk taken into reinsurance.

It is important to note that insurance companies have the same customers of various insurance services that appear in different properties. Namely, although persons, property and liability can be secured, insurance contractors are living people who once appear as car insured, for the second time as insured persons, for the third time as insured persons, ie insured persons in the insurance of a person, and the like.

It can be said that the insurance market allows mass access only to certain assemblies and types of insurance. These assemblies and types of insurance relate mainly to insurance whose obligation is prescribed by law, but also to traditionally accepted insurance, which are so standardized today that they can be offered on the global market.

For all other insurance services, it is necessary to have a differentiated market access. In practice, especially with voluntary property and even more in life insurance, there are customers with different needs, desires and interests. They respond to such requests by the insurance company with an increased range of different insurance services. Customers of these services appear constantly with new demands that insurance companies must satisfy with new and better quality services. In order to achieve a better market approach, it is necessary to conduct market segmentation in order to satisfy the needs of the insured as high as possible, and thus increase the sale of insurance services.

\section{Distortion of insurance services and sales channels}

The sale of insurance consists of all those activities and activities that this service offers to potential insured persons, at the time and place that suits them best. 
The insurance service can be sold in different ways, or it can be distributed to potential insurers in several ways. All the means of distribution of the insurance service could be classified into three groups:

- Sales of insurance through its own sales network of insurers,

- Sales of insurance through insurance agents, i

- Sales of insurance through insurance brokers.

Market coverage of the insurance service means the existence of a security service on the market, measured by the number of facilities through which the service is sold. There are different distribution intensities that affect the coverage of the insurance service: intensive distribution, selective distribution, and exclusive distribution.

Intensive distribution means the situation in which the insurance service is offered and sold to all distribution channels, in the whole market. It is suitable for insurance services which the insured are obliged to contract by law. When distributing these services, it is very important that sales outlets are located near potential customers or institutions that are linked to further customer activities, such as for example the test stations for the technical inspection of motor vehicles.

Selective distribution is the distribution of certain insurance services only in a specific geographic area. Such distribution refers to those services that the insurer can not offer at the moment in the whole market. The reasons for this may be: the specificity of the service, personnel failure, insufficient development of the branch network and branch offices, etc.

Exclusive distribution is used only for a particular market area. Such a case is, for example, insurance of ships, which is mainly related to coastal or river areas, or transport insurance that is concentrated on large transport nodes.

Promotion promotes and convinces potential buyers to accept a particular product or service. It is communication with individuals, with gatherings of people or with organizations, with the aim of directly or indirectly facilitating the sale of services or products. There are two demands that the promotion must answer:

- The source of the message must use characters that are familiar to the recipients of the message, and

- Characters that may have more meaning for the recipient should be avoided.

The aim of the insurance promotion is to create a knowledge of the specific insurance service, and to convince potential insurers of its quality and reliability of the insurers. The problem arises when determining the effect of the promotion, that is, the problem is how to determine the existence of a causal relationship between promotional activities and its effects.

One possible way is to interview potential insurers about the recognition of the name of the insurance companies and its services that are being promoted.

Promotion methods can be divided into: advertising, personal sales, public relations, and sales promotion.

Advertising is a paid form of informing and assuring potential insurers through mass media: radio and television, newspapers, magazines, catalogs, public transport vehicles, etc.

Advertising can be directed to a relatively large target group, but also to a small segment of the population. 
The aim of the advertising can be: promotion of the characteristics of the insurance service, increasing the level of knowledge of the insurance service, information on where the service can be obtained, increasing the market share of the company. (Đokić, 2016, p. 79-93)

The ad text needs to attract attention and create interest in the reader or listener. Therefore, such an approach is called AIDA:

- Attention,

- Interest,

- Desire,

- Action.

Advertising costs are relatively low for one potential policyholder, but they can be significant in the total amount of promotion costs because advertising as a promoter is often used extensively. As a disadvantage, it is emphasized that advertising rarely provides quick feedback on advertising effects.

Personal sales is a form of personal information and assurance of potential insured persons through alternate communication. (Piljan et al, 2017, p. 148) Personal sales are limited to one or several persons as a target group, and provide immediate feedback.

In addition to word communication, communication is also used with body movements (specific movements of the head, eyes, hands, fingers, body position, etc.), and touch communication (handling, tapping, ...).

Publicity and public relations are an unpaid form of informing and assuring potential insurers through a newspaper article or other unpaid promotional material about the insurance company or its services (in journals, in newspapers, on the radio or on television).

There are various special reasons for such promotion, such as opening a new office, hiring new employees, achieving significant business results, achieving significant profit, annual awards, charity actions of the insurance company, and the like.

This kind of promotion is never completely free because certain workers have to collect material, prepare a journalistic story, and perform other activities that require certain material costs.

Sales promotion is part of a promotional mix that encourages customers to make additional purchases of an existing product or service. This is achieved through various sales campaigns, coupons, discounts, prize games, competitions and similar activities, which are intended to encourage and increase sales.

Insurance companies use different methods of promotion. The best combination of all these methods. What methods will the company use and which less depends on the most of the following criteria: available funds for promotion, characteristics of the target market, training and skills of sales staff, choice of channels of sales, and characteristics of the specific insurance service.

\section{Making a decision on insurance purchase}

The insurers are consumers who make a daily decision to purchase a variety of products and services that meet their present and future needs. The speed of purchasing decisions depends on the importance of products and services, on the availability of 
information about products and services, from evaluating possible alternatives, and from the expected effects after purchase.

The purchase of insurance services is, however, a completely specific purchase. It must be kept in mind to buy and sell the promise in writing, but not all insurance services are the same. Some have to buy because they are required by law, and others are purchased voluntarily according to an individual assessment of utility, so the method of making a buyer's choice is different. (Uzelac, 2011, p. 97-105)

Potential insureds come to information about insurance services in different ways. Some of them are: insurance conditions issued by the insurer, various brochures and prospectuses that are printed and distributed by the insurers at points of sale or sent to the insurer's addresses.

Insurance companies also use large posters, or mobile advertisements, such as billboards, indoor and outdoor panels, etc., then information provided by insurers through means of information, television, radio, newspapers, the Internet, etc. they are definitely the source of information intended for a wide range of potential insurers.

Information on the insurer and insurance services can also be found on the website.

Professional journals are a specific way and source of information for policyholders who want more professional and more detailed information about insurance services.

All the listed ways of informing the insured with the services of the insurer are based on the ability to understand the insurance service by the insured.

The best and the most comprehensive, but also the most expensive way to inform insurers about insurance services is to talk to the seller of this service. Such a way of informing about insurance services provides a two-way exchange of information between the representatives of the insurer and the potential insurer. In such a situation it is possible to ask questions and quickly obtain feedback, as well as clarify possible uncertainties regarding the insurance contract.

\section{Channels of distribution of insurance services}

The insurance market is gradually transforming and leaving a centralized management system based primarily on institutional solutions that strongly regulate the operations of insurance companies and which are becoming an increasingly important part of Serbia's financial system. The transformation of the insurance sector is reflected in the fact that ultimately insurance companies as financial intermediaries experience significant changes in the way consumers buy insurance products. Insurance companies that are established as joint-stock companies may place their insurance services through different distribution channels, such as:

- Intermediaries as a channel of distribution of insurance services,

- Representatives as a distribution channel for insurance services,

- Agency as a channel of distribution of insurance services,

- Banking as a channel of distribution of insurance services,

- Internet as a distribution channel of insurance coverage.

This means that individual societies can use and combine different distribution channels, based on institutional solutions. In developed market economies, in addition 
to the mentioned, there are also some specific distribution channels. Of all the aforementioned distribution channels, it is most analyzed and expects, from the point of view of reducing transaction costs, the leading channel of distribution will become an Internet sales channel in the near future. (Cogoljević, Piljan, 2017, p.158-178)

Insurance insurance can be viewed as a process of transmitting information. In order for communication to be understood, the common terminology and the way of communication must be harmonized. Communication starts from the source of the message, and the source can be faces, groups or organizations. The recipient of the message or audience is an individual, group or organization that decodes the previously encrypted message. In the process of decoding, signs turn into concepts, ideas or solutions.

Each communication channel has limitations in the amount of information that can be effectively transmitted. This restriction is called channel capacity. It is also important how promotion is used in relation to the characteristics of the subjects to which it is directed. This is of particular importance since it prescribes behavior, that is, the promotion and acceptance of the insurance service.

Businesses in the insurance industry do not promote only to inform, but communicate in order to facilitate and achieve a satisfactory level of information exchange, or the ultimate promotion effect is determined by the degree to which it creates a willingness to accept a service with a potential buyer or increases the frequency of purchases of potential customers. (Stojanov et al, 2015, p. 146-155)

Insurance is an important process of accepting a service. It is composed of five stages: introduction of services, interest creation, evaluation, checking of effects, and acceptance.

Acceptance of insurance offers is a very important task of promotional activity. There are five basic consequences of promotional communication: the category of need, the knowledge of the content of the policy (the mark of insurance), attitude towards the brand, the intention of buying, and the provision of purchase.

Along with this is a promotional mix. Media mass media are TV, radio, print, post office, catalogs, banners, exhibitions and the Internet.

\section{Evolution of insurance services}

In order to better understand what are the factors that influence the preference of one channel of the distribution of insurance services in relation to the other, it seems useful to analyze some of the existing theoretical views on the adoption of innovations and channels of distribution of insurance services.

One of the factors that leads to the adoption of innovations in terms of introducing new channels of distribution in the insurance services market is precisely the fact of the prevalence of concrete innovation. Thus, Rogers clearly points to the fact that widespread innovation will lead to a significant change in the market of the distribution channel of insurance services, in itself(Rogers, E. 1995). However, the form of adoption of innovations will differ, for example, in the tourism and catering sector in relation to the insurance sector.

The ability to reduce transaction costs in terms of interaction between customers and insurance service providers has always been recognized as a central motive for 
using websites. (Ugrinov, Stojanov, 2011, p. 37) Thus, all predictions about the socalled disintermediation process, or the disappearance of mediators in the distribution of insurance services, were usually based on a reduction in the transaction costs of electronic interaction between customers and insurance service providers. (Tepavac, 2011, p. 115-124) An example is the sale of books by electronic means or the conclusion of transactions in the sale of shares on the stock exchange.

Trust is another factor in the introduction, or adoption of, the Internet as the leading channel for the distribution of insurance services. In particular, it starts from the fact of inverse information, which means that consumers or customers of insurance products are examining the protection of privacy and information security when purchasing insurance policies via the Internet or by electronic purchase of some other products or services, for example through eBay.com. A good example is online shopping in book stores, such as amazon.com. First of all, one should bear in mind that consumers prefer a secure channel of distribution on the basis of which they will make secure payment and purchase of insurance products. (Piljan et al, 2017, p. 367-373)

Banks, insurance companies and clients have different motives for getting banking. For banks, this is a way of product diversification and a source of additional income in the form of commissions from insurance sales, while insurance companies see banking security as a way to increase their market share and total premium income, and clients see bank insurance as a way to get at a reasonable price high quality insurance and in a comfortable way.

Banking uses different distribution channels (so-called sub-channels) and various distribution models. There are three basic models used: an integrative model, a specialist model, a financial planning model.

An integrated model of distribution of insurance services is carried out through existing banking channels and with the help of bank employees, banking officers.

A specialist model distributes insurance services through product experts who are usually employed in or insured by insurance companies.

The model of financial planning is the only model that emphasizes team approach and offers every client the possibility of a complete financial planning package in order to meet the financial needs of the individual.

Each of these models has found its application in practice. It is important to note that the model must be compatible with the bank's database of clients and the strategic goals of the insurance company.

One of the key economic benefits of bank security is savings that are achieved through the efficient use of existing distribution channels of the bank itself. The fact that banks sell their products to each of their clients, while insurers do not say enough. Banks have the advantage of controlling client's financial flows. Information that banks have about their customers' purchasing habits, their economic status and money management are of great importance to insurers.

Banks have increased the conversion rate of potential sale of insurance into real sales by successfully using their customer database, using their customer reputation and existing distribution systems for successful scheduling of meetings (through their own branches, by telephone contact through the Contact Center or by mail distribution), and using sales techniques to distribute customized insurance services for the target market. (Cogoljević, Piljan, 2017, p. 158-178) 
Insurance companies do not have such closeness with their clients and thus face the need to shift their focus from technology and insurance administration to the insurer itself. The current structure of the financial services industry in Europe and America is significantly different, as banks in Europe play a major role in the distribution of insurance products. The percentage of life insurance distribution to individuals across banks varies in European countries from $10 \%$ in Switzerland to as much as $70 \%$ in France, while the percentage of non-life insurance distribution covers $3-10 \%$ of the market.

The situation is not so favorable when it comes to the United States. Recent monitoring results of the Association of American Insurance Banks show that banks increase their marketing efforts, but insurance through banks continues to represent a small percentage of total banking revenue. The percentage of banks participating in some forms of general insurance lines has risen, however, earnings generated in the market of bancassurance are still not satisfactory. The report shows that the bank insurance income makes up less than $0.5 \%$ of the total income that the bank realizes in its operations.

While life insurance products continue to be the dominant insurance products with which banks participate in the market, there is an evident increase in the market for property insurance and accident insurance. Out of the total number of banks, $26 \%$ of the respondents indicated their presence in the auto insurance market and apartment insurance, while an additional $17 \%$ showed an interest in joining the market for these products. Also, more than $10 \%$ of banks surveyed are planning to distribute products for face insurance.

It is interesting to note that there are differences in costs between traditional distribution systems, but it is interesting that these distribution channels continue to function interactively. Strengthening competition in insurance markets should eliminate the system of independent agencies, which means that the lack of competition is the reason why independent agencies and a direct contracting system coexist.

The term »different services« can also explain why different distribution systems coexist. Insurance companies are used by independent agencies as a channel of distribution of insurance services, although they have far higher costs than some other distribution channels. It is reasonable to expect that more expensive distribution channels mean a loss of market share in a competitive market.

Some authors analyzed the benefits of a distribution channel from the perspective of transaction costs and found that independent agencies sell complex insurance types far more often than insurance companies themselves, while exclusive agencies use insurance companies only to sell standardized insurance products. The authors categorized these transactions on the basis of the frequency of the exchange, the complexity of contracting and the importance of some specific investments that can not be transferred to insurance users.

There are also other ways of coexisting multiple distribution channels in parallel. Reasons are found in market imperfections and differences in service quality. Market irregularities are most often caused by price regulation, slow dissemination of information, and spillage transaction costs.

Of particular interest are the results that relate to the change in consumer behavior and the reasons for the online purchase of auto-liability insurance. The results of the survey show that, regardless of the existence of some distribution channels that can be saved on the purchase of insurance services, consumers are inert with regard to accepting 
the purchase of auto-liability insurance, and that they are practically more focused on purchasing policies through independent agents.

\section{Factors of sales success in insurance}

Finally, when the significance of insurance marketing is summed up, the conclusion is that successful sales of insurance services depend on the following several factors:

1. Marketing strategy - goals, skills, plans, tasks, ...;

2. Knowledge of the market of insurance services - knowledge of the potential and target market, creation of market databases, market segmentation, market potential of insurance services, taking into account internal weaknesses and advantages;

3. Marketing approach and flexible attitude towards changes in the environment;

4. Quality of service - a service that fully meets the changing interests and needs of potential insurers, a wide range of coverage, clear and unambiguous insurance conditions, and the introduction of changes in existing insurance services: quality, coverage, discounts, bonuses, malays, etc. The brand of services must be a guarantee of quality, fast, fair and equitable payment of damages or insured sums, quick and correct processing of service damage, notice of expiration of insurance, small gifts to the insured, ...;

5. Respecting the insured as a partner - respecting every insured person, recognizing the needs of the insured, acting in an identical manner at all stages of the business relationship (before concluding, for the duration of the insurance, and after the expiration of the insurance contract), to respect the requirements and needs of the insured, to take into account objections and the insurer's opinion, especially treat the so-called. key insurers, be mute and help insured, keep existing insured because it is much cheaper than finding new, ...;

6. Motivation of sales personnel - good interpersonal relations, job security and secure salary, salary level, stimulation, recognition, status symbols (car, business card, ...), possibility of career advancement;

7. Sales staff training - familiarity with the target market, knowledge and assurance about the quality of insurance services, knowledge of the quality of competition services, quality attitude towards the insured, knowledge of the sales talk technique, manner of dressing and behavior with the insured;

8. Availability of services - different channels of sales, sales at places where insureds most often buy a certain service, location of sales outlets, sales in all places in a particular area, sale based on related business transactions (bank loan, insurance of leased items), sale on the basis of the principle of mutual shops;

9. Quality of service promotion - quality and correct liquidation of damages, communication culture with current and potential insured persons, reaction rate on any request of the insured, advertising, personal sales, publicity and public relations, promotion of sales;

10. Insurance services prices - current and appropriate insurance premium, competitive price, for the same price, better quality of services than competition, discounts, bonuses, flexibility in payment methods are offered; 
11. Insurers 'confidence and security in the insurer - personal experience in dealing with claims, other clients' experience in solving claims, the appearance and behavior of insured employees, public image of insurers, financial strength of the insurer, liquidity and solvency of insurers, tangible assets, office buildings, equipment in offices, vehicle insurers and the like.

\section{Conclusion}

Considering the current level of development of insurance business in Serbia, it is quite realistic to expect a dramatic increase in the volume of operations in some future period. This will require some changes in the work of insurance companies in almost all areas, and the biggest change will require a relationship towards clients, potential insurers. This change in customer relationship will go in two ways: individualizing insurance services and adapting to their individual needs on the one hand, and mass distribution of high-standard insurance services via electronic distribution channels on the other. In both cases, the distribution of insurance plays a key role in the development of the overall activity, but also the insurance companies themselves.

For this reason, the channel of direct sales of insurance, among which the most important banking security, agents and brokers, will remain an irreplaceable distribution channel, and electronic channels will never completely replace them for individualized insurance services. On the other hand, we have electronic distribution channels, and the Internet as the most important and most promising among them, many of which are expected because they can offer large coverage and low distribution costs, although the costs of their introduction and the initial period of exploitation are significant.

The touch point of these two diametrically opposed ways of distributing insurance is CRM (Customer Relationship Management), which should allow direct sales channels to provide greater insurance coverage, and add electronic dimension to the individualization dimension in interaction with the insured. High quality and comprehensive CRM systems are not too represented in insurance companies in Serbia, primarily due to high prices and long-term implementation, but the benefits of using them are obvious and their introduction is inevitable.

We have already said that the Internet as a distribution channel for insurance has great potential, but it is not used at all by domestic insurance companies, primarily because of the economic (the number of able-bodied clients belonging to a specific segment) and technical reasons (the widespread availability of broadband Internet access), but positive changes occur year after year. For this reason, among the first three insurance companies (Generali, Dunav and Uniqa), they have enabled their clients to purchase insurance via the Internet. The sales results of these distribution channels were certainly modest, but their introduction was certainly a matter of prestige, and we can observe them partly as an investment in marketing and promotion. More recently, their example is followed by other insurance companies. 


\section{References}

Cogoljević, D., \& Piljan, I. (2017). Sales of insurance products through a bank channel - bank security, VI INTERNATIONAL Conference Employment, Education and Enterpreneurshi: Finance, Banking and Insurance, book 5, p. 158-178, Belgrade: VŠPEP.

Đokić, I. (2016). Planning integrated marketing communications as part of a strategic marketing plan. Vol. 52, No. 56, p. 79-93, Subotica: Anali Ekonomskog fakulteta u Subotici.

Miletić, V., Curčić, N., \& Miletić, S. (2019). Assessments of Key Factors for Business Improvement and Marketing Concept in Domestic Organizations, No. 2, p. 289304, Belgrade: Vojno delo.

Njegomir, V. (2011). The role of financial derivatives in insurance risk management, vol. 55, No. 3-4., Belgrade: Računovodstvo.

Piljan, I., Cogoljević D., \& Piljan T. (2017). Insurance, College of Business Economics and Entrepreneurship, Belgrade.

Piljan, T., Piljan I., \& Cogoljević, D. (2017). Application of information and communication technologies and the Internet in the distribution of insurance services, No. 6, p. 367-373, Belgrade: Vojno delo.

Simonović, Z., Miletić, S., \& Miletić, V. (2012). The role and importance of marketing in contemporary business, Ekonomika vol. 58, No. 3, p. 102-109, Nis.

Stojanov, A., Ugrinov, D., \& Vaić, E. (2015). Public Sector Financial Audit - A Basis for an Active Business Environment, Transition, Belgrade.

Tepavac, R. (2011). Insurance Sales Channels, vol.55, No. 1-2, Belgrade: Računovodstvo.

Ugrinov, D., \& Stojanov, A. (2011). WEB presentation of the financial statements, vol.6, No. 2, Belgrade: Ekonomski signali.

Uzelac, O. (2011). Legal Aspects of Life Insurance Contracts Observed in Relation to Other Similar Contracts, vol. 28, No. 7-9, Belgrade: Pravo - teorija i praksa. 